\title{
Bathymetric distribution and movements of red mullet Mullus surmuletus
}

\author{
A. Machias ${ }^{1, *}$, S. Somarakis ${ }^{1,2}$, N. Tsimenides ${ }^{1,2}$ \\ ${ }^{1}$ Institute of Marine Biology of Crete, PO Box 2214, GR-71003 Iraklion, Greece \\ ${ }^{2}$ University of Crete, Department of Biology, PO Box 1470, GR-71110 Iraklion, Greece
}

\begin{abstract}
Using data from bottom-trawl surveys conducted each summer, winter and spring on the Cretan shelf from 1988 to 1991, we examined the bathymetric distribution of red mullet Mullus surmuletus. Additionally, we used data from 3 yr (1991 to 1993) of monthly sampling in the Iraklion Gulf. Depth, temperature and salinity data were combined with biological data on abundance, biomass, fish size, age, sex and maturity. The ranges of bottom depth, temperature and salinity over which red mullet is distributed were established. In general, fish size increased with bottom depth, and smaller individuals tended to be found in shallower and warmer water. Abundance increased in mid-shelf waters during spring, indicating a movement across the shelf towards deeper water. The latter seemed to be associated with spawning behavior. The factor controlling the timing of that movement to deep water seemed to be the maturity of individual fish.
\end{abstract}

KEY WORDS: Red mullet - Distribution - Depth selection - Temperature selection - Migration

\section{INTRODUCTION}

Knowledge of the distribution and movement of an exploited stock, particularly during its reproductive phase, is required for proper management of the resource (Mullen 1994, Wroblewski et al. 1995). However, studies on depth, temperature and salinity preferences of marine fishes are widely scattered in the literature and based on few observations (Scott 1982). This is especially true for demersal species on the Mediterranean continental shelf. Caddy (1993) hypothesized the existence of an offshore movement of older fish in several demersal species (e.g. sea breams, common pandora, mullets, etc.), possibly contributing to continuing high recruitment in many areas, as well as to stock recovery. The main problem in the study of these species is that the available data in the Mediterranean come from commercial fisheries, hence there is limited possibility for investigation of the relationships between biological and environmental parameters. Such investigations require long-term research surveys.

\footnotetext{
•E-mail: amachias@talos.cc.uch.gr
}

A general trend for larger fish to occur in deeper water has long been known, especially with respect to deep-sea fishes (Haedrich \& Rowe 1977). The fishes of the inshore zone also seem to undertake an ontogenetic migration to deeper water but there is a paucity of studies on the phenomenon and its causes (Macpherson \& Duarte 1991, Warburton \& Blaber 1992, Blaber et al. 1995). However, there is disagreement as to the generality and the underlying cause of this phenomenon (Macpherson \& Duarte 1991 and references therein, Swain 1993). More detailed studies on the causes of the ontogenetic movements have concentrated on long-lived species, especially cod and plaice (Harden Jones 1968), but similar investigations are lacking for short-lived species like red mullet. Stefanescu et al. (1992) noted that further study of this subject should center on the autoecology of each species, as the complexity of links established by a species with its environment will result in highly variable and specific adaptive responses in each case.

The red mullet Mullus surmuletus (L. 1758) is a common species on the Mediterranean shelf. It is distributed along the eastern Atlantic from the North Sea to the northern part of West Africa (Hureau 1986). In the 
Mediterranean Sea, the red mullet is subject to intensive fishing (Stergiou 1990, Reñones et al. 1995).

Several aspects of red mullet biology have been studied, including feeding, reproduction, age and growth (see Reñones et al. 1995 and references therein), but information on its bathymetric distribution and movements is limited to depth ranges. Hureau (1986) reported that Mullus surmuletus inhabits depths less than $100 \mathrm{~m}$ and Macpherson \& Duarte (1991) found a depth range of 12 to $182 \mathrm{~m}$.

In the present study, we examine the seasonal changes in the distribution pattern of red mullet off the coast of Crete (eastern Mediterranean). Research survey data on distribution, abundance, biomass, size, age, sex and maturity of red mullet were compared with depth, temperature and salinity in order to elucidate factors (e.g. maturation) controlling the seasonal timing and direction of fish movement.

\section{MATERIAL AND METHODS}

Sampling. The seasonal distribution of red mullet at various depths and within various temperature ranges was studied using data from 3 yr of seasonal sampling. Seasonal bottom-trawl surveys were carried out on the Cretan shelf from August 1988 to April 1991. Specifically, one survey was conducted in summer (August to early September), one in winter (December) and one in spring (late March to early April) of each year. Each survey comprised about 40 random, depth-stratified stations, in all areas of the shelf able to be trawled (Fig. 1). Three depth strata were selected (Tsimenides et al. 1991): 26-70 m (stratum I), 71-150 m (stratum II.) and $151-350 \mathrm{~m}$ (stratum III). Stratum I covered $25 \%$, stratum II covered $24 \%$ and stratum III covered $51 \%$ of the total area. Stratum I spanned a substrate covered by algae (Caulerpa prolifera) and sea grass (Posidonia oceanica and Halophila stipulacea); the substrate of stratum II consisted mostly of mud, sand or detritus; and the substrate of stratum III was covered for the most part by crinoids (mostly Leptometra phalangium). All tows were carried out approximately in parallel with the 100 or $200 \mathrm{~m}$ isobaths during daytime. No tows were taken in water deeper than $350 \mathrm{~m}$.

The duration of each haul ranged from 50 to $90 \mathrm{~min}$ at a towing speed of 1.8 to 3 knots, depending on the depth and nature of the bottom. Gear selectivity was assumed to be constant because the same vessel (RV 'Philia') and fishing gear (trawl with a cod-end bag liner of $22 \mathrm{~mm}$ stretched mesh-size) were used in the survey. The catch from each haul was identified to species, enumerated and weighed, and the bottom depth, water temperature and salinity were measured. The door spread of the trawl net was calculated for each haul based on the method of Carrothers (1980). Total area swept was calculated by multiplying the door spread by the vessel speed and the fishing time. Fish abundance was calculated as number of fish or biomass per square nautical mile (n mile ${ }^{2}$ ). The depth of tow was determined by means of an echo-sounder (average depth of tow was used). Bottom temperature and salinity were measured using a SEA-BIRD CTD unit.

Additionally, we used available data from 3 yr of monthly surveys (January 1991 to December 1993) on

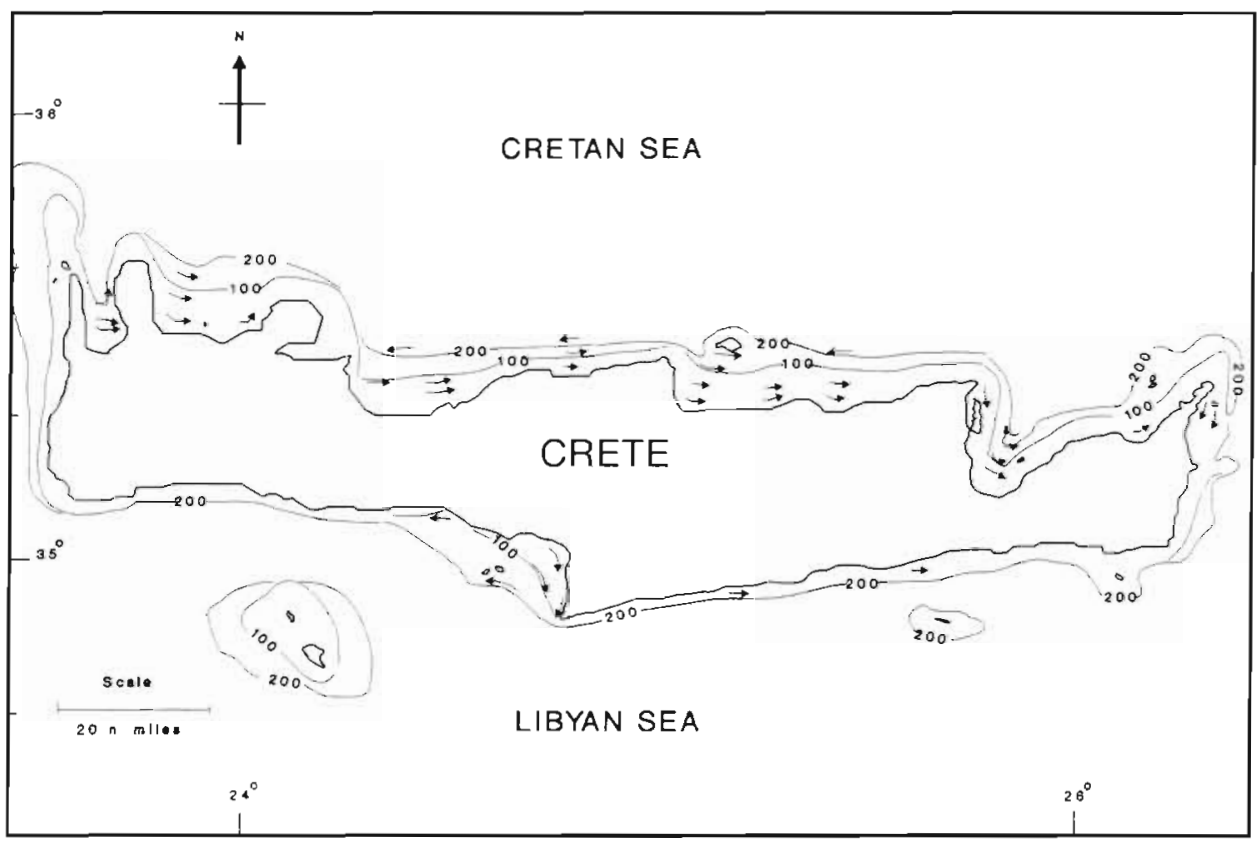

Fig. 1. Map of the sampled area indicating the 100 and $200 \mathrm{~m}$ isobaths as well as the position and direction of the hauls (arrows) 
Table 1 Mullus surmuletus. Female and male maturity stages based on macro. scopic examination of the gonads. Adapted from Macer (1974), Hilge (1977), N'Da \& Deniel (1993)

\begin{tabular}{|c|c|}
\hline Stage & Description \\
\hline \multicolumn{2}{|l|}{ Females } \\
\hline I Immature-resting & $\begin{array}{l}\text { Ovaries small; less than one half of length of ventral } \\
\text { cavity; pale pink to red. No granular appearance }\end{array}$ \\
\hline II Developing & $\begin{array}{l}\text { Ovaries becoming larger; one half of length of ventral } \\
\text { cavity or more; pinkish or yellow. Granular appearance }\end{array}$ \\
\hline $\begin{array}{l}\text { III Late-developing } \\
\text { to running }\end{array}$ & $\begin{array}{l}\text { Ovaries very large; pale yellow or yellow. Transparent } \\
\text { hyaline eggs }\end{array}$ \\
\hline IV Spent & $\begin{array}{l}\text { Ovaries flaccid; pink or red. Early stage of atresia visı- } \\
\text { ble in hyaline oocytes (white spots) }\end{array}$ \\
\hline \multicolumn{2}{|l|}{ Males } \\
\hline I lmmature-resting & $\begin{array}{l}\text { Testes very small; translucent or grey. Less than half } \\
\text { of length of body cavity }\end{array}$ \\
\hline II Developing & $\begin{array}{l}\text { Testes becoming larger and white; more than half of } \\
\text { length of body cavity. Lobed formation }\end{array}$ \\
\hline $\begin{array}{l}\text { III Late-developing } \\
\text { to running }\end{array}$ & $\begin{array}{l}\text { Testes very large and multilobed; creamy white or } \\
\text { pinkish; free-flowing milt }\end{array}$ \\
\hline IV Spent & Testes flaccid; possibility of a little residual milt \\
\hline
\end{tabular}

circuli in the lateral field, close spacing of circuli followed by wider spacing in the anterior field, and consistency of these characteristics in at least 4 of the scales examined per fish.

Age classes were assigned according to number of scale annuli, marginal-increment spacing, month of collection, and size relative to the length frequency distribution (Ross 1988). We used May 1 as the birthdate, based on the results of the gonad study and on unpublished data from ichthyoplanktonic investigations in the same area. A total of 1526 specimens were aged and the von Bertalanfy growth curve (VBGC) was estimated as in Tserpes \& Tsimenides (1995).

Growth curves for females and males were estimated separately and compared by analysis of residual sum of squares (Chen et al. 1992). Since the 2 VBGCs were not significantly

the shelf of the Iraklion Gulf (off central northern Crete). These data provided complementary and temporally more detailed information on changes in the depth distribution of red mullet. These additional data were from a total of 19 hauls for each month (at least 5 hauls at each station). Each monthly survey comprised a trawl at each of 3 stations (1 in each of the 3 strata) using the same gear and sampling method as in the seasonal surveys.

Biological sampling. During the 9 seasonal surveys, either all specimens or a random subsample of at least 100 individuals from each haul were measured and weighed. The following measurements were taken for each specimen: total length to the nearest $\mathrm{mm}$, total and eviscerated mass to the nearest $0.1 \mathrm{~g}$, and gonad mass to the nearest $0.1 \mathrm{mg}$. The sex and the macroscopic stage of maturity (Table 1) were also determined and a gonosomatic index calculated $\left(\mathrm{GSI}=\frac{\text { gonad weight }}{\text { eviscerated body weight }} \times 100\right)$. All data were transformed to number of individuals per $n$ mile ${ }^{2}$.

To study growth, scales were collected from all specimens during the first year of seasonal surveys, and from fish larger than $220 \mathrm{~mm}$ during subsequent surveys. Six scales from each specimen, taken from the region under the pectoral fin, were cleaned with water, placed on $0.3-\mathrm{mm}$-thick cellulose acetate plates and pressed at a temperature of $105^{\circ} \mathrm{C}$ for $3 \mathrm{~min}$. Subsequently, the scales were removed and their imprints on the plates were examined using a binocular micrascope. Annuli were identified using the standard criteria of Bagenal \& Tech (1978), especially cutting-over of different $(F=0.015, \mathrm{p}>0.05)$ data were pooled and the resulting curve was used for a deterministic aging of all fish caught, using the equation

$$
t=t_{0}-\frac{1}{k} \ln \left(1-\frac{L_{t}}{L_{w}}\right)
$$

where $L_{l}$ is total length at age $t_{i} L_{\infty}$ is asymptotic length; $k$ is growth coefficient; $t_{0}$ is theoretical age at zero length (Hilborn \& Walters 1992).

Data analysis. After logarithmic transformation (Middleton \& Musick 1986, Stefanescu et al. 1992), means of abundance (ind. $n$ mile ${ }^{-2}$ ) and biomass ( $\mathrm{g} n \mathrm{mile}^{-2}$ ) were calculated for each cruise (1) for each $50 \mathrm{~m}$ bottom-depth interval, and (2) per stratum (I, II, III). Furthermore, the seasonal distribution of the total abundance and biomass for each stratum or bottom-depth interval were calculated by weighting the mean values with the ratio of the surface area of the stratum or bottom-depth interval to the total area.

Analysis of variance showed no differences in abundance or biomass among the 3 surveys in the same season, nor among the 3 strata (1, II, III) in the same season $(0.177<p<0.730$; Bartlett's test, $0.101<p<0.562)$. For each season, results and conclusions were similar and independent of whether survey-specific or pooled data were used. Hence, only the latter are presented here.

A correlation analysis (Pearson's correlation coefficient) was performed to determine if there were any significant changes in abundance or biomass with bottom depth or water temperature. The same method was used to test the hypothesis that fish size is depth dependent. Fish size was also tested for any significant correlations with temperature. Geometric mean was 
preferred for calculation of the mean fish size of each sample, because the arithmetic mean is susceptible to the influence of a few large specimens and does not represent accurately the mode in fish size at a given station (Stefanescu et al. 1992). To test the hypotheses 'fish size is depth dependent', 'larger individuals tend to be found in deeper water' and 'smaller fish tend to be found in shallow water', correlation analysis was performed between depth and mean, minimum or maximum length (Middleton \& Musick 1986, Macpherson \& Duarte 1991, Stefanescu et al. 1992). The same 3 variables were used in correlation analysis with respect to temperature.

The distribution of different-sized fish was simplified, as follows: Lengths were converted to ages using Eq. (1). We examined relationships between red mullet density (ind. $n$ mile $e^{-2}$ ) and temperature or bottom depth using cumulative distribution functions (CDFs) following Perry \& Smith (1994). The CDF (in \%) for temperature (available temperature) or bottom depth (available depths), $f(t)$, was calculated for each season as follows:

$$
f(t)=100 \frac{\sum_{h=1}^{L} \sum_{i=1}^{n_{h}} \frac{A_{h}}{n_{h}} I}{\sum_{h=1}^{L} \sum_{h=1}^{n_{h}} \frac{A_{h}}{n_{h}}} \quad \text { where } I= \begin{cases}1, & \text { if } x_{h i}<t \\ 0 & \text { otherwise }\end{cases}
$$

and $t$ is a level of temperature or bottom depth; $A_{h}$ is the area of stratum $h_{;} n_{h}$ is the number of tows in stratum $h_{i} x_{h}$ is the bottom temperature or depth of tow $i$ in stratum $h_{i} L$ is the number of strata. The CDF for red mullet catch, $g(t)$, was calculated similarly:

$$
g(t)=100 \frac{\sum_{h=1}^{L} \sum_{i=1}^{n_{h}} \frac{A_{h}}{n_{h}} y_{h i} I}{\sum_{h=1}^{L} \sum_{j=1}^{n_{h}} \frac{A_{h}}{n_{h}} y_{h i}} \quad \text { where } I= \begin{cases}1, & \text { if } x_{h i}<t \\ 0 & \text { otherwise }\end{cases}
$$

and $y_{h i}$ is the number of red mullet caught in tow $i$ in stratum $h$. We calculated the red mullet CDF separately for each age 0 to 2 and for fish age 3 and older (Swain \& Krammer 1995).

To examine seasonal variation in temperature or bottom depth selection by red mullet, we compared CDFs of temperature, $f(t)$, and red mullet catch, $g(t)$, in relation to temperature, as well as CDFs of bottom depth and red mullet catch in relation to bottom depth. We calculated

$$
S=\sum_{t=1}^{t}[f(t)-g(t)]
$$

for each season and age group. $S$ compares average available temperature or depth to the average temperature or depth selected by red mullet. Positive values of $S$ indicated that the red mullet select high temperatures and depths within the ranges studied here. We used a Kolmogorov-Smirnov type of statistic to test the significance of temperature and bottom depth selection. The test statistic $D$ was defined $D=\max |f(t)-g(t)|$ (maximum absolute vertical distance) when $f(t)$ and $g(t)$ were the 2 functions compared at $0.2^{\circ} \mathrm{C}$ (CDFs of temperature) or $10 \mathrm{~m}$ (CDFs of depth) intervals. Significance was assessed using randomization tests (Perry \& Smith 1994, Swain \& Krammer 1995).

Standardized numbers of males and females in the 4 different maturity stages (Table 1), by age class, were used in the spring sampling to examine differences in maturity among strata. All statistical inferences were based on the 0.05 significance level

\section{RESULTS}

\section{Abundance and biomass}

A total of 6280 individuals were analyzed. Muilus surmuletus was distributed between depths of 28 and $310 \mathrm{~m}$, between temperatures of 13.6 and $23.8^{\circ} \mathrm{C}$ and between salinities of 38.12 and $39.75 \%$ (Table 2). Salinity showed very small variation and is noi generally considered to affect the distribution of fishes on the

Table 2. Seasonal ranges of depth, temperature and salinity in which red mullet occurred in the period 1988 to 1991

\begin{tabular}{lccc|} 
& Min. & Max. & Range \\
\hline Depth (m) & & & \\
Spring & 28 & 300 & 272 \\
Summer & 28 & 273 & 245 \\
Winter & 28 & 310 & 282 \\
Temperature $\left.{ }^{\circ} \mathrm{C}\right)$ & & & \\
Spring & 14.5 & 17.3 & 2.8 \\
Summer & 14.4 & 23.8 & 9.4 \\
Winter & 13.6 & 17.8 & 4.2 \\
Salinity (\%o) & & & \\
Spring & 38.65 & 39.05 & 0.4 \\
Summer & 38.12 & 39.75 & 1.63 \\
Winter & 38.66 & 39.23 & 0.57 \\
\hline
\end{tabular}

\begin{tabular}{|c|c|c|c|c|}
\hline & \multicolumn{2}{|c|}{ Abundance } & \multicolumn{2}{|c|}{ Biomass } \\
\hline & $r$ & $p$ & r & $\mathrm{p}$ \\
\hline \multicolumn{5}{|l|}{ Depth } \\
\hline Spring & -0.490 & 0.000 & -0.430 & 0.000 \\
\hline Summer & -0.591 & 0.000 & -0.520 & 0.000 \\
\hline Winter & -0.679 & 0.000 & -0.635 & 0.000 \\
\hline \multicolumn{5}{|c|}{ Temperature } \\
\hline Spring & 0.231 & 0.253 & 0.221 & 0.260 \\
\hline Summer & 0.673 & 0.001 & 0.669 & 0.002 \\
\hline Winter & 0.342 & 0.083 & 0.335 & 0.091 \\
\hline
\end{tabular}

Table 3. Mullus surmuletus. Correlation between red mullet abundance and biomass and depth and temperature 


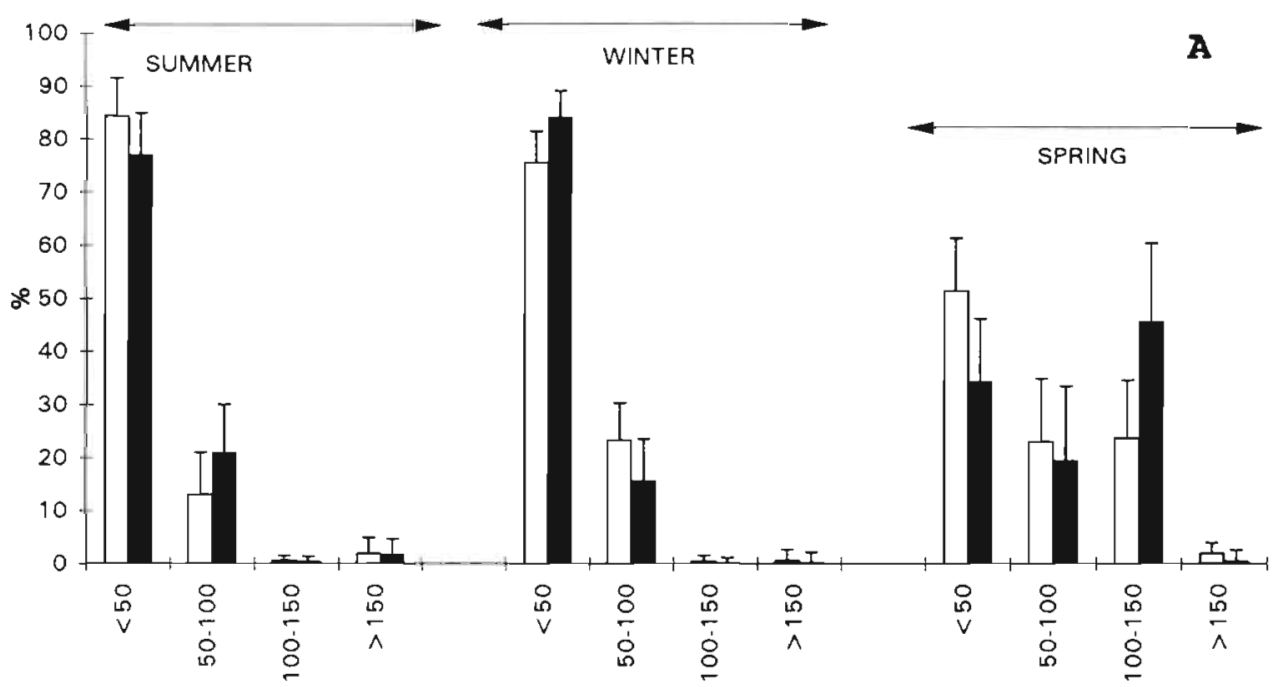

Fig. 2. Mullus surmuletus. Seasonal distribution by abundance and biomass (A) in $50 \mathrm{~m}$ depth intervals ( $\mathrm{m}$ ) and $(\mathrm{B})$ in the 3 strata. I: stratum I (20-70 m); II: stratum II $(71-150 \mathrm{~m}) ;$ III: stratum III $(151-350 \mathrm{~m})$
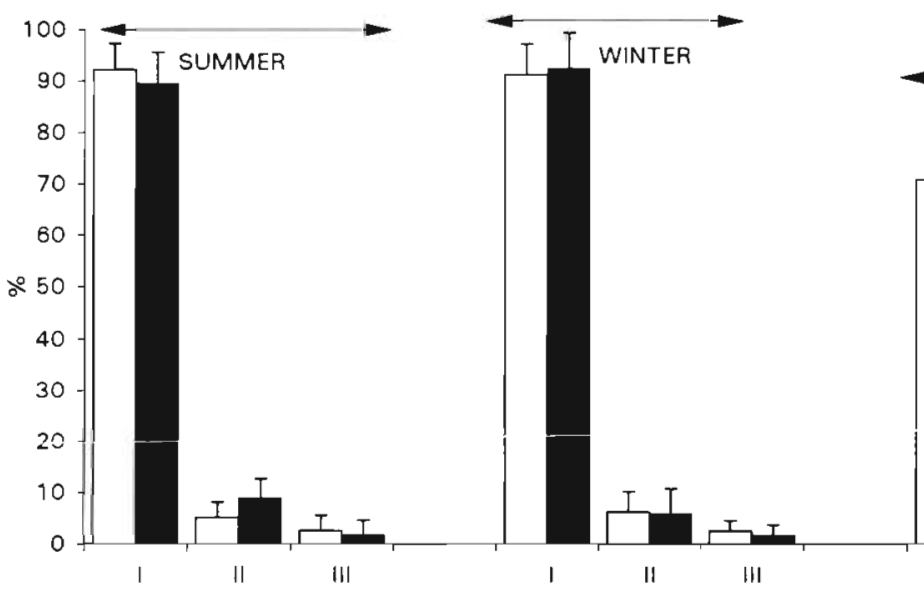

B

$\square$ Abundance $\square$ Biomass

Cretan shelf (Tsimenides et al. 1991). Abundance and biomass were significantly negatively correlated to bottom depth during all seasons and positively correlated to temperature during summer (Table 3). No significant correlations between abundance or biomass and temperature were observed during winter and spring. The lack of correlations could be mainly attributed to the small temperature variation during these seasons (Table 2).

Relative percentage of abundance and biomass by depth interval (Fig. 2) indicated that fish generally occurring in shallow waters increased their presence at mid-shelf depths (stratum II) during spring. A similar change was observed in the monthly collections in the Iraklion Gulf (Fig. 3). Fig. 3 shows that, after the aforementioned change in May, abundance and biomass remained low in stratum I and high in stratum II up to recruitment during July-August. Thus, the existence of a seasonal, depth-related movement is suggested.

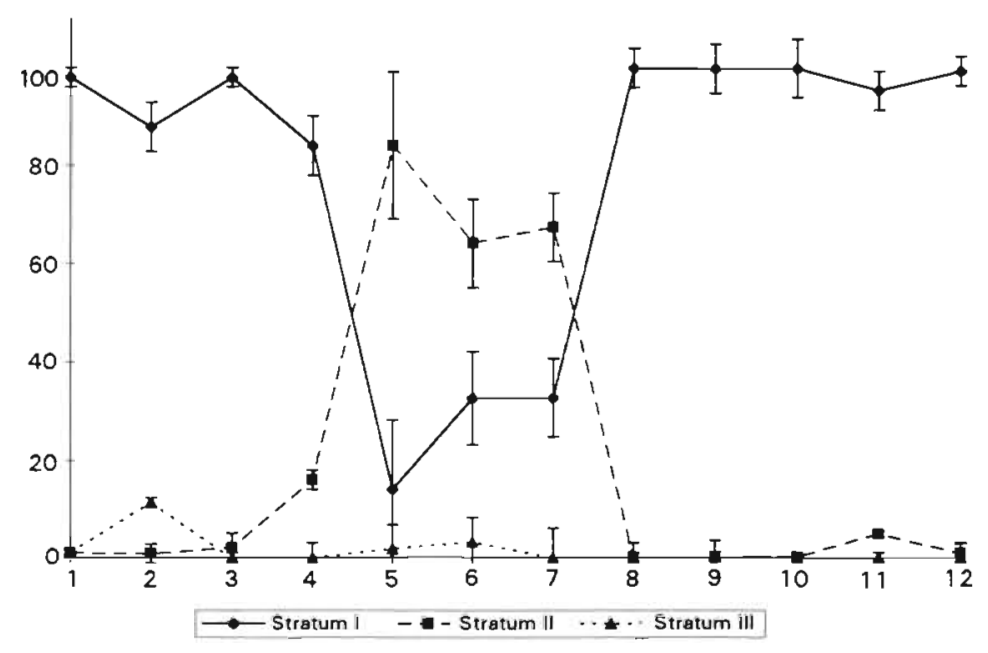

Fig. 3. Mullus surmuletus. Monthly distribution in the Iraklion Gulf, by abundance in the 3 strata ( $I, I I, I I I)$. Months are numbered from January (1) to December (12) 
Table 4. Correlation between mean, minimum and maximum total length (TL) of red mullet and depth and temperature

\begin{tabular}{|lccccccc} 
& \multicolumn{3}{c}{ Mean TL } & \multicolumn{2}{c}{ Min. TL } & \multicolumn{2}{c}{ Max. TL } \\
& $\mathrm{r}$ & $\mathrm{p}$ & $\mathrm{r}$ & $\mathrm{p}$ & $\mathrm{r}$ & $\mathrm{p}$ \\
\cline { 1 - 5 } & & & & & & \\
Depth & 0.645 & 0.000 & 0.631 & 0.000 & 0.204 & 0.107 \\
Spring & 0.791 & 0.000 & 0.801 & 0.000 & 0.573 & 0.002 \\
Summer & 0.833 & 0.000 & 0.814 & 0.000 & 0.465 & 0.005 \\
Winter & & & & & & \\
Temperature & -0.215 & 0.108 & -0.203 & 0.107 & -0.198 & 0.125 \\
Spring & -0.670 & 0.000 & -0.651 & 0.000 & -0.632 & 0.000 \\
Summer & -0.601 & 0.000 & -0.661 & 0.000 & -0.354 & 0.082 \\
Winter & & & & & & \\
\hline
\end{tabular}

\section{Fish size}

The relationships between mean total length (TL) and depth were significantly positive in all seasons (Table 4). The maximum TL of the samples increased with depth during summer and winter. Minimum TL of the samples increased with depth in all seasons. The relationship between mean TL and temperature was negative in summer and winter, but there was no significant correlation in spring. During summer, maximum length was negatively correlated with temperature. Length
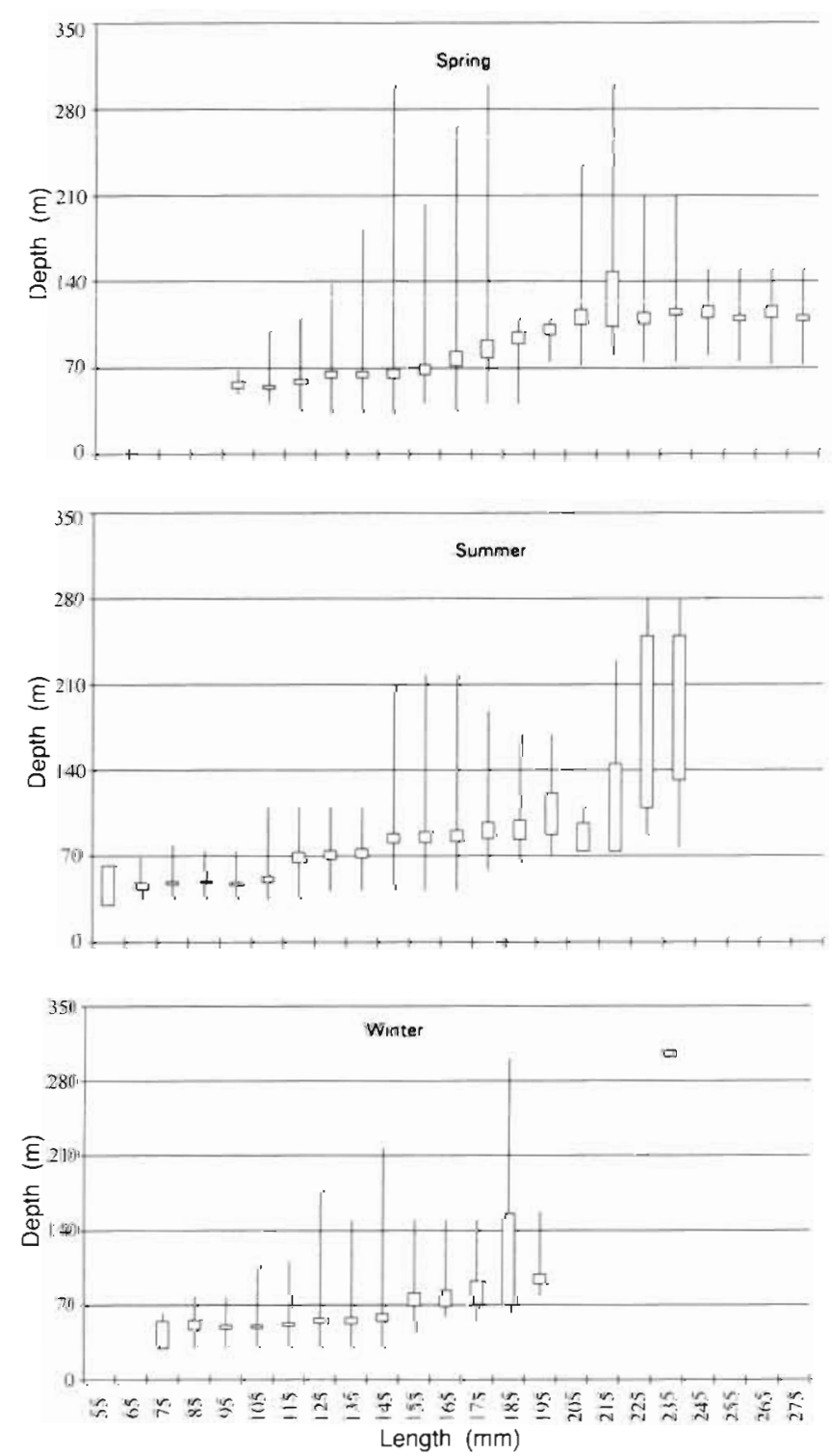

Fig. 4. Mullus surmuletus. Seasonal graph of fish total length vs depth. Rectangles represent $95 \%$ confidence intervals and lines represent corresponding ranges distribution by depth revealed that individuals larger than $155 \mathrm{~mm}$, which is the length at first maturity (Reñones et al. 1995), were generally found in stratum II during summer and winter (Fig 4). The same was found for individuals larger than $165 \mathrm{~mm}$ in spring.

\section{Age}

The calculated VBGC is shown in Fig. 5. 0 yr old fish were found in shallow water, while $3+$ yr old fish were found in deep water. 1 and 2 yr old fish selected intermediate bottom depths (Fig. 6). A randomization test based on the absolute maximum vertical distance between CDFs indicated significant shallow depth selection for the age 0 group during summer and winter and significant selection for greater depths for the age $3+$ group during spring and summer (Table 5). Fish

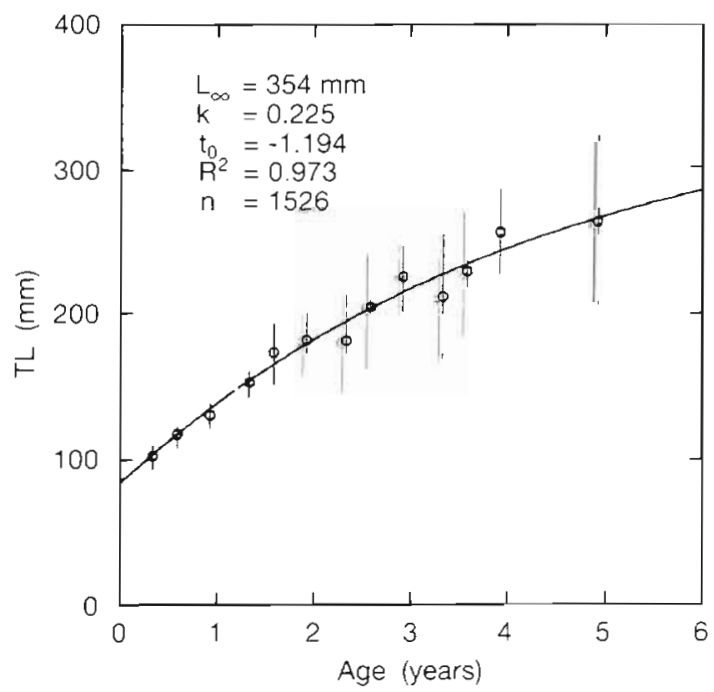

Fig. 5. Mullus surmuletus. The von Bertalanffy growth curve Points correspond to the mean $( \pm S E)$ values for each age. $L$. asymptotic total length; $k$ growth coefficient $t_{0}$ : theoretical age at zero length; $R^{2}$ coefficient of determination; $n$ : number of specimens 

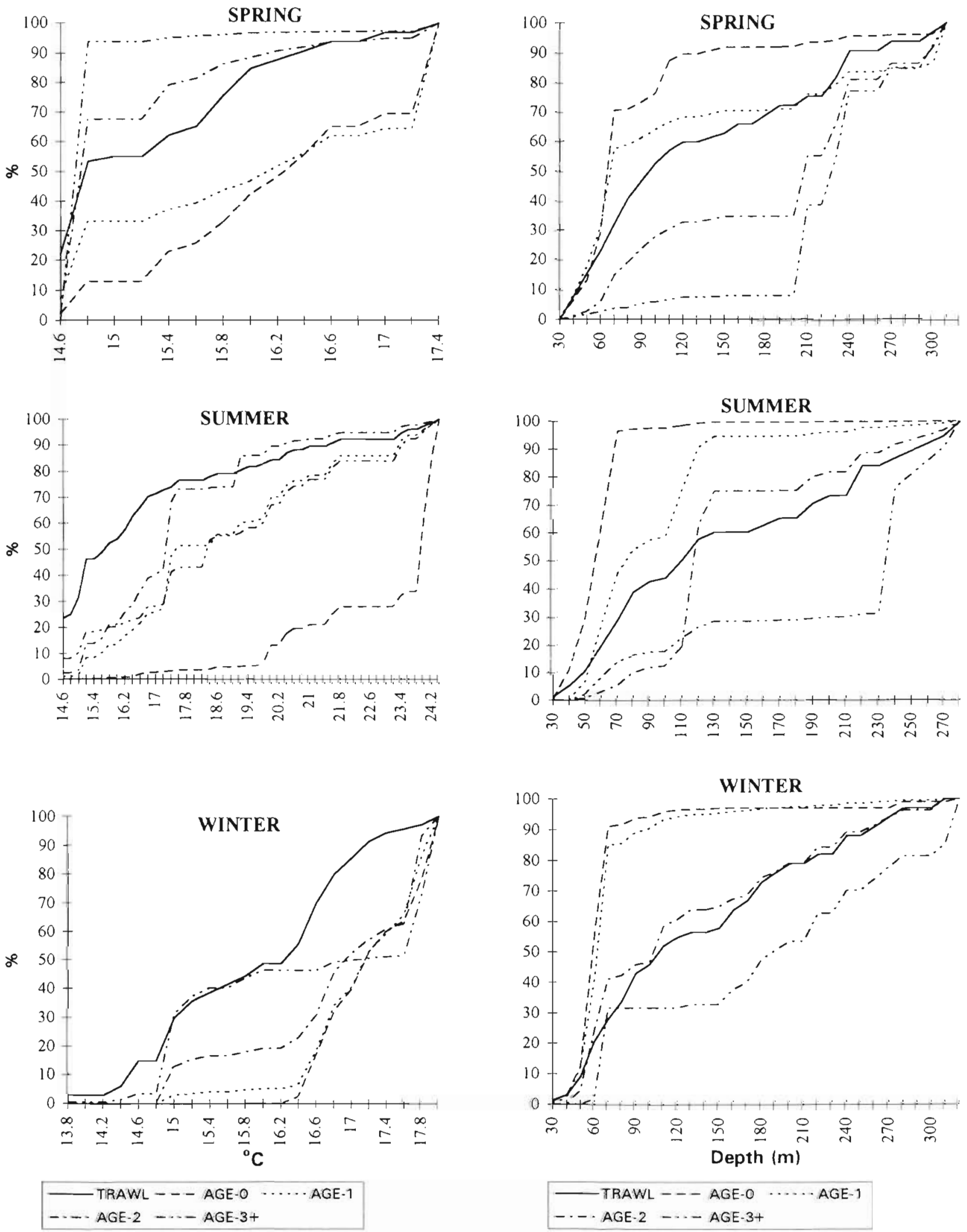

Fig. 6. Mullus surmuletus. Cumulative distribution function of red mullet catch in relation to available temperature and bottom depth 
Table 5. Indexes of bottom depth and temperature selection by season. $S$ : index of bottom depth or temperature selection; $D$ : test statistic; $\mathrm{p}$ : probability of statistical significance of depth or temperature selection based on the randomization test described in the text

\begin{tabular}{|c|c|c|c|c|}
\hline & Age 0 & Age 1 & Age 2 & Age 3+ \\
\hline \multicolumn{5}{|c|}{ Depth } \\
\hline \multicolumn{5}{|c|}{ Spring } \\
\hline$S$ & -455.13 & -71.27 & 545.71 & 935.90 \\
\hline$D$ & 38.43 & 25.36 & 37.47 & 67.21 \\
\hline $\mathrm{p}$ & 0.593 & 0.759 & 0.281 & 0.005 \\
\hline \multicolumn{5}{|c|}{ Summer } \\
\hline$S$ & -766.71 & -439.78 & 47.10 & 640.06 \\
\hline$D$ & 67.67 & 34.43 & 31.42 & 52.91 \\
\hline $\mathrm{p}$ & 0.015 & 0.291 & 0.714 & 0.004 \\
\hline \multicolumn{5}{|c|}{ Winter } \\
\hline$S$ & -668.41 & -631.46 & -66.55 & 482.11 \\
\hline$D$ & 62.88 & 56.95 & 13.09 & 26.82 \\
\hline $\mathrm{p}$ & 0.049 & 0.089 & 0.982 & 0.764 \\
\hline \multicolumn{5}{|c|}{ Temperature } \\
\hline \multicolumn{5}{|c|}{ Spring } \\
\hline$S$ & 495.40 & 398.39 & -68.01 & -215.14 \\
\hline$D$ & 42.78 & 37.95 & 19.58 & 40.44 \\
\hline $\mathrm{p}$ & 0.624 & 0.791 & 0.989 & 0.984 \\
\hline \multicolumn{5}{|c|}{ Summer } \\
\hline$S$ & 3049.68 & 1010.42 & 387.70 & 1018.23 \\
\hline$D$ & 76.77 & 45.56 & 34.13 & 43.90 \\
\hline $\mathrm{p}$ & 0.002 & 0.741 & 0.922 & 0.748 \\
\hline \multicolumn{5}{|c|}{ Winter } \\
\hline$S$ & 654.83 & 607.65 & 457.93 & 287.18 \\
\hline$D$ & 53.25 & 51.93 & 39.35 & 44.047 \\
\hline $\mathrm{p}$ & 0.005 & 0.003 & 0.150 & 0.198 \\
\hline
\end{tabular}

older than 3 yr did not generally occur in shallow water (stratum I), which was dominated by young fish.

The temperature selection of red mullet showed a pattern consistent with the depth distribution pattern. Younger fish selected high temperatures within the ranges we studied here (Fig. 6). A randomization test indicated significant selection of the age 0 group for high temperatures during summer and winter and of the age 1 group, likewise, during winter (Table 5). A randomization test did not indicate any significant temperature selection in spring due to the small temperature variation with depth.

\section{Maturity}

All individuals collected during summer and winter were immature or resting (Stage I). During spring (late March to early April) most individuals were in early or late maturation (Stages II, III), but no spent individuals (Stage IV) were found, indicating that spawning takes place later in the season. Percentages of the different maturity stages by age group in snallow waters (stratum I) and in deeper waters (strata II and III) are shown in Fig. 7. Only a very small percentage of $0+$ fish were in advanced maturation in stratum $I_{\text {, }}$ whereas most individuals were in an advanced maturity stage in strata II and III. This is also indicated by the GSI (Fig. 8). It seems, overall, that the movement to midshelf depths is associated with reproduction.
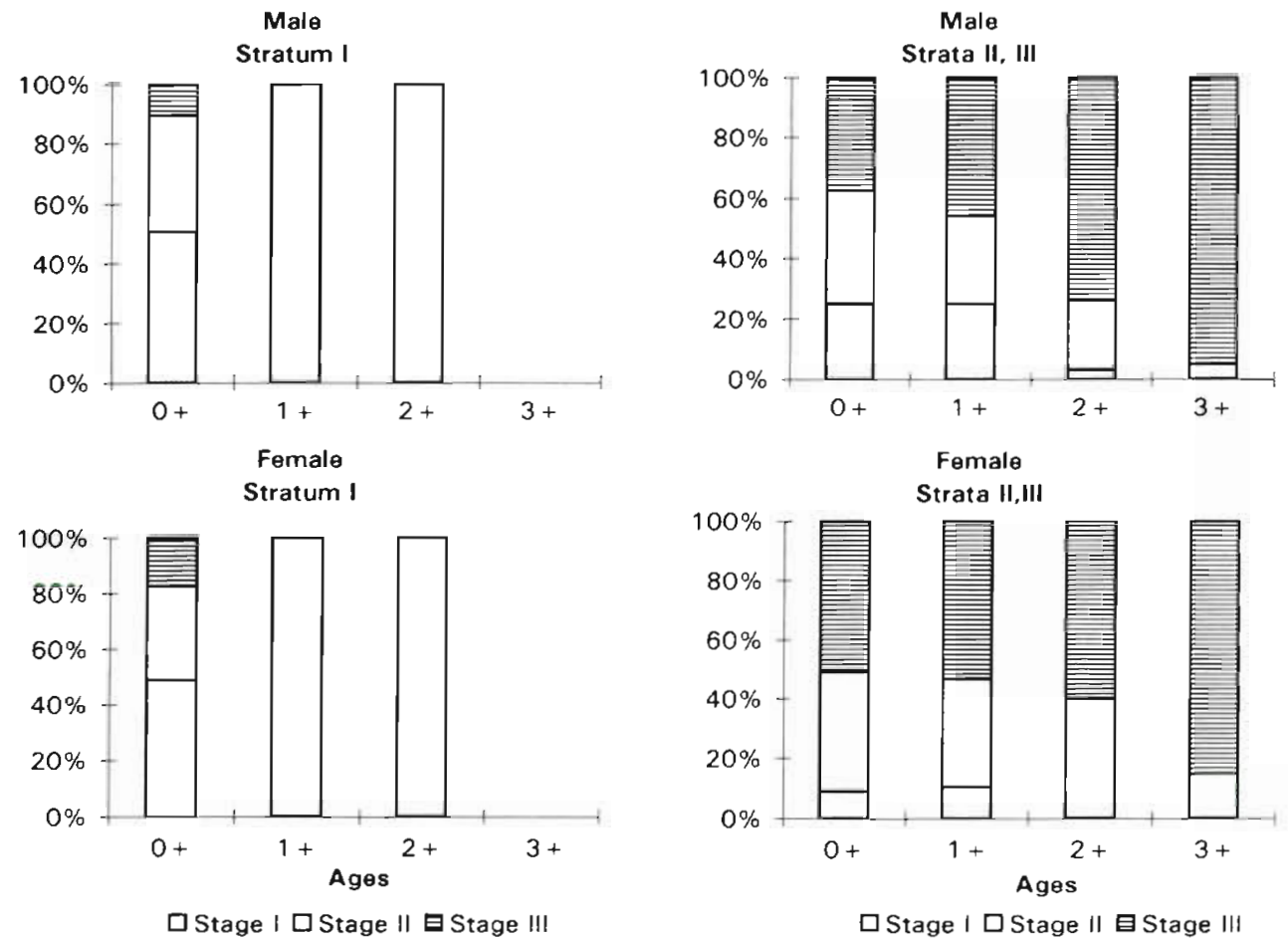

Fig. 7 Mullus surmuletus Percentage of the maturity stage (see Table 1) by stratum, sex and age in spring; $0+: 0-0.99 \mathrm{yr}$ olds $1+$ : $1-1.99$ yr olds; $2+$ $2-2.99$ yr olds; and $3+$ fish older than $3 \mathrm{yr}$ 
Fig. 8. Mullus surmuletus. Mean gonosomatic index (GSI), with $95 \%$ confidence intervals, by stratum, sex and age, in spring; age classes as in Fig. 7
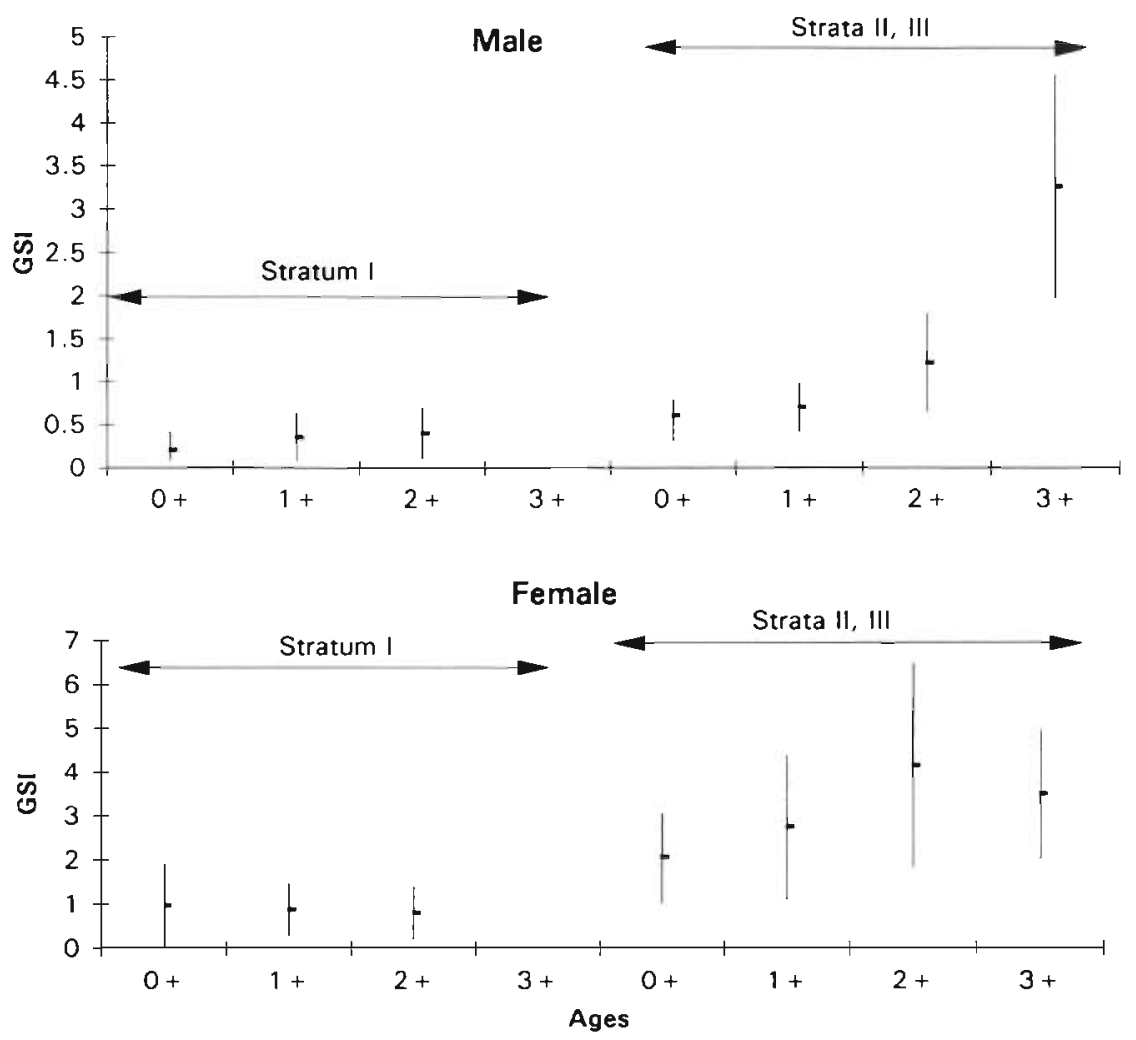

\section{DISCUSSION}

There is a well-known general trend for size to increase with depth in most demersal fishes. The general nature of this size-depth relationship could derive from migratory or diffusive movements to deeper water during ontogeny (Cushing 1975). The preponderance of the positive size-depth relationships in fish species may reflect a fundamental aspect of fish life history or it could be the result of sampling artifact, e.g. size-dependent catchability, or selective fishing pressure (Stefanescu et al. 1992). However, sampling artifacts are unlikely to account for this in our research survey data, because the sampling gear and methods were the same throughout the sampling, a reasoning previously followed by Snelgrove \& Haedrich (1985). Additionally, selective fishing pressure is also unlikely to be the reason for this observation, since it is intensive throughout the sampling area (Tsimenides et al. 1991). A further question is whether the relationship reflects a progressive increase in fish size with increasing depth.

The phenomenon of older specimens being found at greater depths has sometimes been taken as a rule (Heinke's law), as in the case of plaice (Harden Jones 1968). The occurrence of smaller, younger individuals in shallower water and the movement towards deeper waters during ontogeny must involve a substantial advantage. It has been suggested that, by migrating to deeper waters, the adults could benefit from a reduced basal metabolic rate and increascd life expectancy at lower temperature (Macpherson \& Duarte 1991); there is also a density-dependent variation in bathymetric pattern (Swain 1993). Since, in the Mediterranean, the water temperature remains virtually constant below a depth of 160 to $200 \mathrm{~m}$, Macpherson \& Duarte (1991) suggested that this behavior represents an inherited evolutionary response and, therefore, has a genetic basis

According to our results, Mullus surmuletus is among the species that show a positive relationship between mean length and depth. The analysis revealed that the smaller individuals tend to be found in shallower water during all seasons, whereas the larger fish tend to be found in deeper waters during summer and winter. In other words, smaller individuals tend to occupy warmer (high energy cost) shallower (high resourcel grounds, and the older individuals colder, deeper grounds.

A change in the distribution of Mullus surmuletus occurs in spring just before spawning, which takes place during April-May (Reñones et al. 1995). This change is mainly attributable to a movement of individual fish from stratum I to stratum II. In addition, individuals in the final stages of gonadal maturation were generally absent from stratum I but abundant in strata II and III. Thus, final maturation seems to be accompanied by a movement of fish to deeper water. 
In Crete, wind-driven currents flow in the coastal area in April-May (Tselepides et al. 1996). These currents may prevent larval dispersal away from the continental shelf. Furthermore, mullids have a pre-juvenile pelagic stage (Kendall et al. 1984, Watson 1996) which makes it advantageous to the mullids to settle in appropriate areas.

Stratum I is covered mainly by Posidonia and is the substrate where red mullet recruitment occurs (García-Rubies \& Macpherson 1995). The trend of increasing mean length with depth in summer and winter is due primarily to recruitment during July-August and secondarily to the occurrence of larger fish in deeper water. The change in the distribution during spring could be attributed to the concentration of the immature specimens in shallow water and of fish approaching maturity in strata II and III. The vast movement from Posidonia beds to deeper water seems to be related to the final stage of gonad maturation, rather than directly to fish size. Individuals $1+$ and $2+$ yr old captured in stratum I seem to be the fish that had not reached maturity or that happened to be on the edge of stratum I. Alternatively, larger individuals may attain final maturation earlier than smaller ones and/or some individuals may spawn in stratum I. However, results of the monthly surveys (Fig. 3) support better the first hypothesis.

An ontogenetic movement (after maturation) to deeper water might have the advantage of reducing inter-specific competition (Warburton \& Blaber 1992). Stratum I (Posidonia beds) is inhabited by a much greater number of species than the other strata (Tsimenides et al. 1991). It is the nursery ground of most Mediterranean demersal species (García-Rubies \& Macpherson 1995). However, inter-specific competition in this stratum might be low as a result either of a temporary adjustment in the occupation of the shallow zone (Warburton \& Blaber 1992, García-Rubies \& Macpherson 1995) or of a shift in feeding habits (Labropoulou \& Plaitis 1995, Labropoulou \& Eleftheriou 1997). The movement of larger fish to greater depth could be a part of a strategy for better exploitation of the shallow zone by a greater number of species. Although no cannibalism has been reported, fish prey only made an important contribution to the diet of red mullet larger than $171 \mathrm{~mm}$ (Labropoulou et al. 1997). The latter are generally found in deep water (stratum II). Therefore, size-selective habitat use may also function as a defense against cannibalism on other conspecifics.

Intra-specific competition could also be relaxed by movement of larger fish to deeper water, e.g. by means of a bathymetric adjustment triggered by first maturity. Additionally, this timing results in the smaller, rapidly growing individuals inhabiting the shallow competitive stratum I for the minimum necessary time.

The movement of red mullet follows a definite pattern and could be considered as migration. The fish are spawned in stratum II, they are recruited in stratum I and subsequently return to the stratum in which they were born to reproduce. The following points may be made: (1) there seems to be a bathymetric rather than. a geographical determination of the 'immature' and 'mature' segregation, so there is no 'homing'; (2) there was a short-distance rather than a long-distance movement; and (3) we found no evidence for any seasonal migration cycle. Nevertheless, this pattern seems to have an evolutionary origin, namely (1) a possible adaptive value in the tendency to dissociate the mature from immature individuals, and (2) a possible adaptive value of the timing of the 'evacuation' of the recruitment ground by older fish.

The same pattern of 'inter-depth' migration, related to reproduction, has been observed in deep-sea fishes (Middleton \& Musick 1986). A difference is that the red mullet, instead of returning to shallow water after reproduction, continues dispersing into deeper waters. The absence of a correlation between maximum length and depth in the spring could be due to a movement from deep water to stratum II, but there was no clear evidence for that.

The stocks of red mullet in the Mediterranean Sea are considered to be heavily exploited (Caddy 1993). The existence of bathymetric movements in this species has ecological but also management implications. From a management perspective, it has generally been assumed that closure of trawl fisheries during the summer months (June to September) and in waters shallower than $50 \mathrm{~m}$ would be an effective means of increasing the biomass of fish available to the fisheries. Results of this study suggest that this management policy is successful in protecting the immature fraction of the population, but reproducing adults are fully vulnerable to overfishing, especially during spawning This might cause a decrease in recruitment by decreasing the number of reproducing females.

Much of what fisheries management tries to achieve is aimed towards maintaining a sufficient biomass of reproductively active fish to replenish stocks (Roberts 1997). As pointed out by Stergiou \& Pollard (1994), the multi-species, multi-gear nature of Greek fisheries (and of the Mediterranean fisheries in general) poses difficulties in designing and implementing protective measures. They suggest that the creation of marine harvest refugia may be potentially well applicable in the case of the Aegean Sea demersal fisheries. Such protected areas would allow a proportion of the stock to grow to a relatively large size at which overall. fecundity is greatly increased. 
Acknowledgements. We thank Professor B. Nafpaktitis and Dr R. Griffiths for their critical reading of an earlier version of this manuscript, as well as the 3 anonymous reviewers for their valuable comments. We also thank A. Kallianiotis, G. Tserpes and K. Vidalis and the crew of the RV 'Philia' for their help in collecting the fish samples.

\section{LITERATURE CITED}

Bagenal TB, Tech FW (1978) Age and growth. In: Bagenal TB (ed) Methods for assessment of fish production in fresh waters, 3rd edn. Blackwell Scientific Publications, Oxford, p $101-136$

Blaber SJ, Brewer DT, Salini JP (1995) Fish communities and the nursery role of the shallow inshore waters of a tropical bay in the Gulf of Carpentaria, Australia. Estuar Coast Shelf Sci 40(2):177-193

Caddy JF (1993) Some future perspectives for assessment and management of Mediterranean fisheries. Sci Mar 57 : $121-130$

Carrothers PJG (1980) Estimation of trawl door spread from wing spread. J Northwest Atl Fish Sci 1:81-89

Chen Y, Jackson DA, Harvey HH (1992) A comparison of von Bertalanffy and polynomial functions in modeling fish growth data. Can J Fish Aquat Sci 49:1228-1235

Cushing DH (1975) Marine ecology and fisheries. Cambridge University Press, Cambridge

García-Rubies A, Macpherson E (1995) Substrate use and temporal pattern of recruitment in juvenile fishes of the Mediterranean littoral. Mar Biol 124:35-42

Haedrich RL, Rowe GT (1977) Megafaunal biomass in the deep sea. Nature 269:141-142

Harden Jones DH (1968) Fish migration. Edward Arnold (Puibi) Ltü, Luncion

Hilborn R, Walters CJ (1992) Quantitative fisheries stock assessment. Chapman and Hall, London

Hilge $V$ (1977) On the determination of the stages of gonad ripeness in female bony fishes. Meeresforschung 25: $149-155$

Hureau JC (1986) Mullidae. In: Whitehead PJP, Bauchot ML, Hureau JC, Nielsen J, Tortonese E (eds) Fishes of the North-eastern Atlantic and the Mediterranean, Vol 2. UNESCO, Paris, p 877-882

Kendall AW. Ahlstrom EH, Moser HG (1984) Early life history stages of fishes and their character Ontogeny and systematic of fishes. Am Soc Ichthyol Herpetol Spec Publ $1: 11-22$

Labropoulou M, Eleftheriou A (1997) The foraging ecology of two pairs of congeneric demersal fish species: importance of morphological characteristics in prey selection. J Fish Biol 50:324-340

Labropoulou M. Machias A, Tsimenides N, Eleftheriou A (1997) Feeding habits and ontogenetic diet shift of the striped red mullet Mullus surmuletus Linnaeus, 1758. Fish Res 31:257-267

Labropoulou M, Plaitis W (1995) Selective predation on small crustaceans by six demersal fish species in Iraklion bay (Cretan Sea, north-eastern Mediterranean). In: Eleftheriou A, Ansell AD, Smith CJ (eds) Biology and ecology of shallow coastal waters. Olsen and Olsen, Fredensborg, p 351-357

Macer CT (1974) The reproductive biology of the horse mackerel Trachurus trachurus (L.) in the North Sea and English Channel. J Fish Biol 6:415-438

Macpherson E, Duarte CM (1991) Bathymetric trends in dem- ersal fish size: is there a general relationship? Mar Ecol Prog Ser 71:103-112

Middleton RW, Musick JA (1986) The abundance and distribution of the family Macrouridae (Pisces: Gadiformes) in the Norfolk Canyon area. Fish Bull US 84:35-62

Mullen AJ (1994) Effects of movement on stock assessment in a restricted-range fishery. Can J Fish Aquat Sci 51: 2027-2033

N'Da K, Deniel C (1993) Sexual cycle and seasonal changes in the ovary of the red mullet, Mullus surmuletus, from the southern coast of Brittany. J Fish Biol 43:229-244

Perry RI, Smith SJ (1994) Identifying habitat associations of marine fishes using survey data: an application to the northwest Atlantic. Can J Fish Aquat Sci 51:589-602

Reñones O, Massutí E, Morales-Nin B (1995) Life history of the red mullet Mullus surmuletus from the bottom-trawl fishery off the Island of Majorca (north-west Mediterranean). Mar Biol 123:411-419

Roberts CM (1997) Ecological advice for the global fisheries crisis. Trends Ecol Evol 12:35-38

Ross SW (1988) Age, growth and mortality of Atlantic croaker in North Carolina, with comments on population dynamics. Trans Am Fish Soc 117:461-473

Scott JS (1982) Depth, temperature and salinity preferences of common fishes in the Scotian shelf. J Northwest Atl Fish Sci 3:29-39

Snelgrove PVR, Haedrich RL (1985) Structure of the deep demersal fish fauna off Newfoundland. Mar Ecol Prog Ser $27: 99-107$

Stefanescu C, Rucabado J, Lloris D (1992) Depth-size trends in western Mediterranean demersal deep-sea fishes. Mar Ecol Prog Ser 81:205-213

Stergiou KI (1990) Prediction of the Mullidae fishery in the eastern Mediterranean 24 months in advance. Fish Rcs $9: 67-74$

Stergiou KI, Pollard DA (1994) A spatial analysis of the commercial fisheries catches from Greek Aegean Sea. Fish Res 20:109-135

Swain DP (1993) Age and density-dependent bathymetric pattern of Atlantic cod (Gadus morhua) in the Southern Gulf of St. Lawrence. Can J Fish Aquat Sci 50:1255-1264

Swain DP, Krammer DL (1995) Annual variation in temperature selection by Atlantic cod Gadus morhua in the southern Gulf of St. Lawrence, Canada, and its relation to population size. Mar Ecol Prog Ser 116:11-23

Tselepides A, Papadopoulou KN, Polychronaki T (1996) CINCS: pelagic-benthic coupling in the oligotrophic Cretan Sea. MAST II MTP, MAS 2 CT94-0092

Tserpes G, Tsimenides N (1995) Determination of age and growth of swordfish, Xiphias gladius L. 1758, in the eastern Mediterranean using anal fin spines. Fish Bull US 93. $594-602$

Tsimenides N, Tserpes G, Machias A, Kallianiotis A (1991) Distribution of fishes on the Cretan shelf. J Fish Biol 39: $661-672$

Warburton K, Blaber SJM (1992) Patterns of recruitment and resource use in a shallow-water fish assemblage in Moreton Bay, Queensland. Mar Ecol Prog Ser 90:113-126

Watson W (1996) Mullidae: goatfishes. In: Moser HG (ed) The early stages of fishes in the California current region. Allen Press Inc, Lawrence, Atlas No. 33:1034-1037

Wroblewski JS, Kulka DW, Narayanan S, Oake AM, Collier AG, Grath BC (1995) Winter distribution and movements of northern Atlantic cod (Gadus morhua) along the Newfoundland-Labrador continental shelf edge derived from observations on commercial trawlers. Fish Oceanogr 4: $128-146$ 